\title{
Meme kanseri olan Türk kadın hastalarda meme dansitesinin klinik ve patolojik bulgularla ilişkileri
}

\author{
The relationship between breast density and clinical and pathological findings in Turkish \\ female patients with breast cancer
}

Nihan Turhan, Dilek Yılmaz, Levent Yeşilyurt

Gönderilme tarihi:16.08.2021

Kabul tarihi:12.10.2021

\section{Öz}

Amaç: Meme kanseri, kadınlarda kansere bağlı ölüm nedenleri arasında tüm dünyada çok büyük bir tehdit oluşturmaktadır. Uzun yıllardır meme kanseri etiyolojisine yönelik çalışmalar yapılmaktadır. Memenin radyolojik dansite yoğunluğunun meme kanseri üzerinde etkili olduğunun gösterilmesi ile bu konuda çalışmalar hızlanmıştır. Yapılan çalışmalarda meme dansitesinin farklı etnik kökenli toplumlar arasında değişiklikler gösterdiği sunulmuştur. Çalışmamızda Türk uyruklu meme kanseri hastalarının meme dansiteleri ile meme kanseri ilişkisi araştırılmıştır.

Gereç ve yöntem: Çalışmamızda 01.01.2018-01.01.2021 tarihleri arasında hastanemizde tedavi edilen Türk uyruklu meme kanseri hastalarında meme dansitesi, yaş, menopoz durumu, vücut kitle indeksi ve tümörün patolojik özelikleri retrospektif olarak değerlendirilmiştir.

Bulgular: Elde edilen veriler ışığında meme dansitesinin yaş arttıkça ve post-menopozal dönemde ve vücut kitle indeksinin arttığı durumlarda istatistiksel açıdan anlamlı olarak düşük olduğu gösterilmiştir. Ancak meme dansitesi ile tümör boyutu ve patolojik belirteçler arasında anlamlı bir ilişki saptanamamıştır.

Sonuç: Meme dansitesi, meme kanseri için başta obezite durumu ve hormonal değişimler ile bireyin ömrü boyunca değişen ve modifiye edilebilen bir risk faktörüdür. Meme dansitesi yoğun hastaların tanınması, meme kanseri riskini azaltıcı önlemlerin alınması ve gereklilik halinde ek görüntüleme yöntemleri ile daha sık aralıklarla izlenmeleri gerekmektedir.

Anahtar kelimeler: Meme kanseri, meme dansitesi, patoloji.

Turhan N, Yılmaz D, Yeşilyurt L. Meme kanseri olan Türk kadın hastalarda meme dansitesinin klinik ve patolojik bulgularla ilişkileri. Pam Tıp Derg 2022;15:309-317.

\begin{abstract}
Purpose: Breast cancer is one of the leading causes of cancer-related death in women all over the world. Studies on the ethiology of breast cancer have been carried out for many years. With the demonstration of the radiological breast density as a risk factor on breast cancer, studies on this subject have been accelerated. Studies have shown that breast density varies between societies with different ethnic origins. In our study, the relationship between breast density and breast cancer in Turkish breast cancer patients is investigated.

Materials and methods: In our study, breast density, age, menopausal status, body mass index and pathological features of the tumor were evaluated retrospectively in Turkish breast cancer patients treated in our hospital between 01.01.2018-01.01.2021.

Results: According to the data obtained, it has been shown that breast density is statistically significantly lower as age increases, in the post-menopausal period and as body mass index increases. However, no significant relationship was found between breast density and tumor size and pathological markers.

Conclusion: Breast density is a risk factor for breast cancer that can be changed and modified throughout the life of the individual, primarily by obesity and hormonal changes. Patients with dense breast should be identified, taken measures to reduce the risk of breast cancer and followed more frequently with additional imaging methods if necessary.
\end{abstract}

Key words: Breast cancer, breast density, pathology.

Turhan N, Yilmaz D, Yesilyurt L. The relationship between breast density and clinical and pathological findings in Turkish female patients with breast cancer. Pam Med J 2022;15:309-317. 


\section{Giriş}

Meme kanseri gün geçtikçe insidansı ve mortalite oranı artan çok önemli bir sağlık problemidir. Dünya verileri değerlendirildiğinde gelişmekte olan ülkelerde kadınlarda meme kanseri, kansere bağlı ölümlerin en sık nedenidir [1]. Türkiye verilerine göre de kansere bağlı ölümler arasında kadınlarda ilk sırada meme kanseri yer almaktadır [2]. Türkiye'de 1994 ve 2015 yılları verileri değerlendirildiğinde meme kanseri insidansının çok hızlı arttığı görülmektedir (24/100.000-43,8/100.000) [2, 3].

Meme kanserinin bu kadar yaygın olması, ilgili hekimlerin dikkatini uzun yıllardır çekmiş ve etiyolojiye yönelik çalışmaları da beraberinde sürüklemiştir. Meme kanseri riskini artıran faktörler arasında BRCA 1 ve BRCA 2 gen mutasyonları, erken menarş, geç menopoz, ilk doğum yaşının geç olması, hormon replasman tedavisi, alkol, obezite, inaktivite, glisemik indeksi yüksek, yağlı, et ürünlerinden zengin, taze sebze ve meyvelerden fakir beslenmenin üzerinde durulmuştur $[4,5]$.

Bu faktörlerden farklı olarak özellikle son 10 yıldır radyolojik olarak ölçülen meme dansite oranının meme kanseri riski ile ilişkisinin gündeme gelmesi araştırmalara yeni bir boyut kazandırmıştır [6-8]. Meme dansitesinin daha yoğun olduğu hastalarda diğerlerine göre ileri evre meme kanseri riskinin daha fazla olduğu bildirilmiştir [7, 9].

Meme dansitesinin meme kanseri hastalarında patolojik ve immünolojik özellikler açısından prognostik önemi olduğunu da gösteren çalışmalar bulunmaktadır [9].

Meme dansitesi ve meme kanseri ile ilgili literatürdeki ilk çalışmalar çoğunlukla Batı kökenli hasta gruplarında yapılmış, daha sonra Doğu ülkelerinden bildirilen çalışmalar ile farklı toplumlar arasındaki benzerlikler ve farklılıklar üzerinde durulmuştur [10, 11].

Türkiye'nin konumunun Doğu ve Batı arasında olması nedeniyle Türk uyruklu kadınlardaki meme dansite oranlarının ve dansitenin meme kanseri ile ilişkisinin bildirilmesi önemlidir.

Çalışmamızın amacı, hastanemizde tedavi edilen Türk uyruklu meme kanseri hastalarında meme dansitesi ile meme kanseri arasındaki ilişkileri değerlendirmektir.

\section{Gereç ve yöntem}

Çalışmamızda hastanemize 01.01.201801.01.2021 tarihleri arasında başvuran meme kanseri tanısı almış, Türk uyruklu hastalarının retrospektif olarak dosya verilerine ulaşılarak memenin radyolojik dansitesinin hastanın yaşı, menopoz durumu, vücut kitle indeksi, tümörün patolojik belirteçleri ile ilişkisi değerlendirildi.

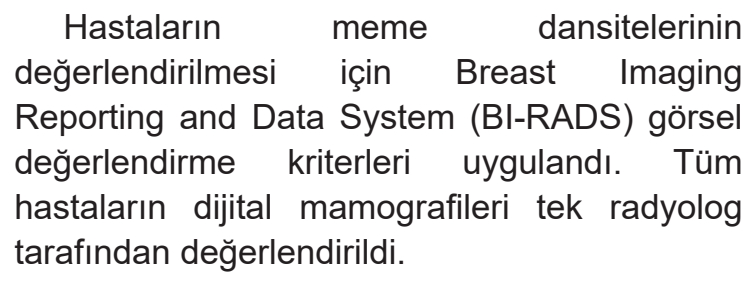

Hastaların menopoz durumu, boy ve kilo değerleri için dosya kayıtları değerlendirildi. Dosya kayıtlarında veri eksikleri olan hastalar telefon ile aranarak meme kanseri teşhisi konduğu zamanki menopoz, boy ve kilo değerleri sorgulandı.

Hastaların obezite derecesini değerlendirmek için Dünya Sağlık Örgütü tarafından tanımlanan Vücut Kitle İndeksi (VKI) kullanıldı. VKI'si 25 $\mathrm{kg} / \mathrm{m}^{2}$ nin altında olanlar normal, 25-29,9 kg/ $\mathrm{m}^{2}$ arasında olanlar fazla kilolu, $30 \mathrm{~kg} / \mathrm{m}^{2}$ ve üzerinde olanlar ise obez olarak değerlendirildi.

Patolojik olarak meme kanseri hastalarından alınan doku örneklerinden tümör boyutu, tümör tipi, Östrojen ve Progesteron reseptör durumu, HER 2 pozitifliği, Ki 67 proliferasyon indeksi ve tümörün grade’i değerlendirildi.

Tümör boyutu değerlendirilirken TNM sınıflandırmasındaki tümör çapı değerleri baz alınarak hastalar tümör çapı $2 \mathrm{~cm}$ ve altında olanlar, $2-5 \mathrm{~cm}$ arasında olanlar ve $5 \mathrm{~cm}$ üzerinde olanlar olmak üzere üç gruba ayrıldı.

Tümörün histolojik tipi değerlendirilirken hastalar, spesifik alt grubu olmayan duktal, lobüler, dukto-lobuler miks tip olan ve özel tip meme kanseri gruplarına ayrıldı.

Östrojen (ER) ve progesteron reseptör (PR) pozitifliği değerlendirilirken güncel American Society of Clinical Oncology (ASCO) / College of American Pathologists (CAP) rehberine göre hastalar pozitif ve negatif gruplara ayrıldı.

Meme kanserinin hücrelerinin invaziv olma potansiyelini gösteren HER 2 reseptör durumu immunohistokimyasal teknikler ile ölçüldü. Tümörün immunohistokimyasal alt tiplendirmesi 
Luminal $A(E R+/ P R+$, HER 2 -), Luminal B $(E R+/ P R+$, HER $2+)$, HER 2 pozitif (ER -, PR -, HER $2+$ ) ve triple negatif ( ER -, PR -, HER 2 -) olarak yapıldı.

Ki 67 değeri günümüzde tümörün prognozunun değerlendirilmesi ve verilecek neoadjuvan - adjuvan tedavinin seçilmesinde yol gösterici olmaktadır. Bizim çalışmamızda Penault Llorca ve ark. [12] yaptığı derleme sonucu belirttiği \%25 sınırı değerlendirme limiti olarak seçildi.

Hastaların tümör gradeleri değerlendirilirken Nottingam Histolojik Skor skalasından faydalanıldı.

\section{İstatistiksel değerlendirme}

İstatistiksel analizler SPSS versiyon 15 yazılımı kullanılarak yapıldı. Elde edilen verilerin meme dansitesine göre durumları çapraz tablolar kullanılarak verildi. Gruplar arasında sıklıklar bakımından fark olup olmadığı Pearson Ki-kare testi kullanılarak karşılaştırıldı. p değerinin 0,05'in altında olduğu durumlar istatistiksel olarak anlamlı olarak kabul edildi.
Çalışma için, İstanbul Sancaktepe Şehit Prof. Dr. İlhan Varank Eğitim ve Araştırma Hastanesi, Girişimsel Olmayan Klinik Araştırmalar Etik Kurulu'ndan onay alınmıştır.

\section{Bulgular}

Türk uyruklu olmayan 5 hasta ve mamografi filmlerine ulaşılamayan 4 hasta çalışma dışına alındı. Çalışmaya dahil edilen 113 hastanın yaş dağılımı 28 ile 93 arasındaydı. Hastaların yaş ortalaması 53,95 olarak bulundu.

Mamografik olarak değerlendirilen meme dansitelerine göre $15(\% 13,3)$ hasta Tip A, 49 $(\% 43,4)$ hasta Tip B, $33(\% 29,2)$ hasta Tip C, $16(\% 14,2)$ hasta Tip D meme yapısına sahipti.

Hastaların meme dansite gruplarına göre ortalama yaşları değerlendirildiğinde, meme dansitesi Tip A olanlarda ortalama yaş 68,33, Tip B grubunda 58,18, Tip C grubunda 46,97, Tip D'de ise 41,94 olarak hesaplandı. Meme dansitesi düşük olan gruplarda yaş ortalamasının yüksek olması istatistiksel olarak anlamlı bulundu. Ancak Tip C ile Tip D grupları arasında yaş dağılımı açısından net istatistiksel fark olmadığı saptandı $(p<0,001) \quad($ Tablo 1) (Grafik 1).

Tablo 1. Meme dansitelerine göre yaş ve menopoz durumları

\begin{tabular}{|c|c|c|c|c|c|c|c|c|c|}
\hline & \multicolumn{2}{|c|}{ Tip A } & \multicolumn{2}{|c|}{ Tip B } & \multicolumn{2}{|c|}{ Tip C } & \multicolumn{2}{|c|}{ Tip D } & \multirow[t]{2}{*}{ p değer } \\
\hline & $\mathrm{n}$ & $\%$ & $\mathrm{n}$ & $\%$ & $\mathrm{n}$ & $\%$ & $\mathrm{n}$ & $\%$ & \\
\hline Hasta sayısı & 15 & 13,3 & 49 & 43,4 & 33 & 29,2 & 16 & 14,2 & \\
\hline Yaş (ortalama & \multicolumn{2}{|c|}{$68,33 \pm 12,97$} & \multicolumn{2}{|c|}{$58,18 \pm 11,14$} & \multicolumn{2}{|c|}{$46,97 \pm 5,67$} & \multicolumn{2}{|c|}{$41,94 \pm 8,35$} & $<0,001$ \\
\hline \multicolumn{10}{|l|}{ Menopoz } \\
\hline Pre-menopoz & 1 & 6,66 & 14 & 28,57 & 24 & 72,72 & 12 & 75,00 & $<0,001$ \\
\hline Post-menopoz & 14 & 93,33 & 35 & 71,42 & 9 & 27,27 & 4 & 25,00 & \\
\hline
\end{tabular}

SS; standart sapma

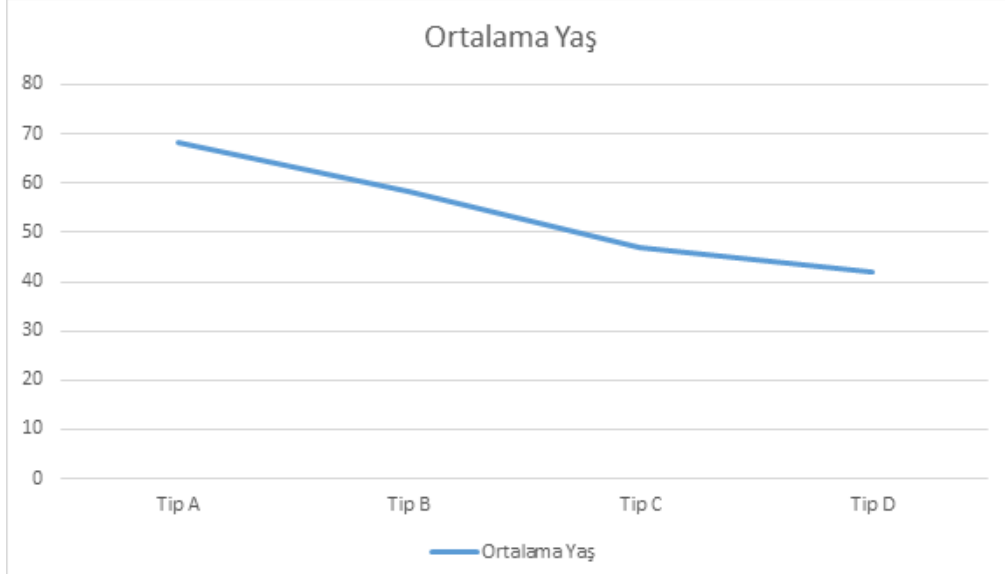

Grafik 1. Meme dansitesi - ortalama yaş 
Hastaların 51'i $(\% 45,13)$ pre-menopozal, 62 'si $(\% 54,87)$ post-menopozal dönemdeydi. Meme dansitesi ve menopoz durumu değerlendirildiğinde, meme dansitesi yüksek olan hastaların daha sıklıkla pre-menopozal dönemde olduğu saptandı $(p<0,001)$ (Tablo 1).

Hastaların ortalama VKİ değeri 27,99 olarak hesaplandı. Hastaların meme dansitelerinin VKI'lerine göre dağılımları değerlendirildiğinde meme dansitesi arttıkça ortalama VKİ değerinin düştüğü $(p=0,05)$, meme dansite yoğunluğu düşük olan gruplarda fazla kilolu ve obez hastaların daha sık görüldüğü saptandı $(p=0,001)$ (Tablo 2) (Grafik 2).

Hastaların ortalama tümör boyutu 24,44 mm olarak hesaplandı. Meme dansitesi ile ortalama tümör boyutları değerlendirildiğinde, Tip A meme paterni olan hastalarda $30,73 \mathrm{~mm}$, Tip B olan hastalarda $23,00 \mathrm{~mm}$, Tip C olan hastalarda 23,61 mm, Tip D olan hastalarda ise 24,69 $\mathrm{mm}$ bulundu. Ortalama tümör çapının meme dansitesine göre istatistiksel olarak anlamlı farklılık göstermediği saptandı $(p=0,120)$ (Tablo 3).

Tablo 2. Meme dansitelerine göre VKİ değerleri

\begin{tabular}{|c|c|c|c|c|c|c|c|c|c|}
\hline & Tip A & & Tip B & & Tip C & & Tip D & & $p$ değeri \\
\hline & $\mathrm{n}$ & $\%$ & $\mathrm{n}$ & $\%$ & $\mathrm{n}$ & $\%$ & $\mathrm{n}$ & $\%$ & \\
\hline \multicolumn{10}{|l|}{ VKi } \\
\hline Ortalama VKI & 31,27 & & 28,09 & & 27,44 & & 25,74 & & 0,05 \\
\hline$<25 \mathrm{~kg} / \mathrm{m}^{2}$ & 2 & 13,33 & 5 & 10,20 & 6 & 18,18 & 5 & 31,25 & 0,001 \\
\hline $25-29,9 \mathrm{~kg} / \mathrm{m}^{2}$ & 3 & 20,0 & 32 & 65,30 & 20 & 60,60 & 11 & 68,75 & \\
\hline$\geq 30 \mathrm{~kg} / \mathrm{m}^{2}$ & 10 & 66,66 & 12 & 24,48 & 7 & 21,21 & 0 & 0,0 & \\
\hline
\end{tabular}

VKi; Vücut Kitle İndeksi

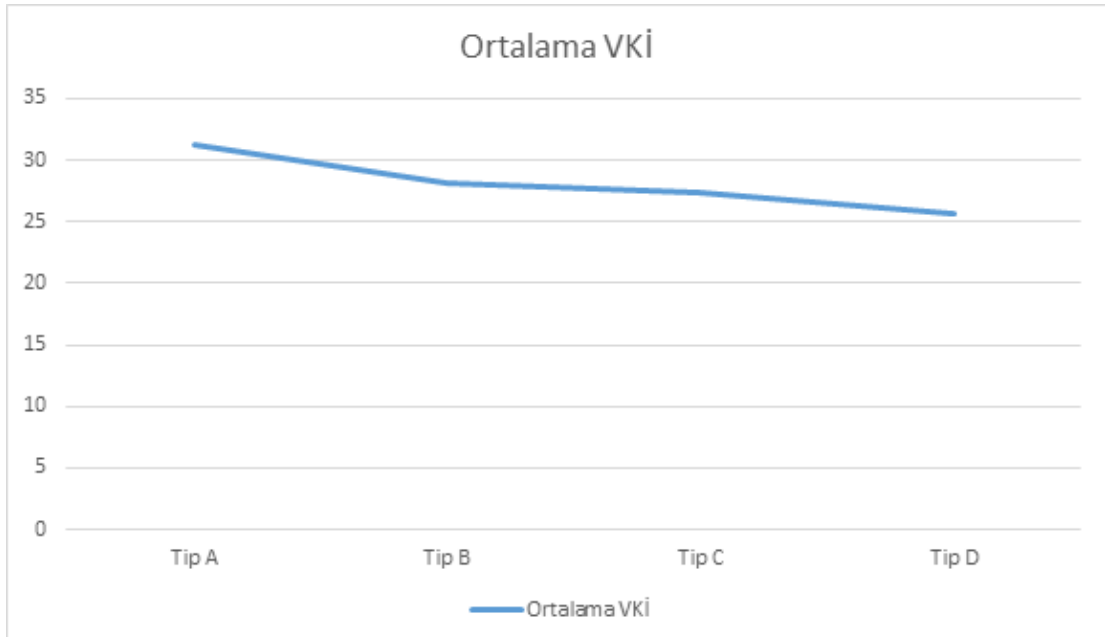

Grafik 2. Meme dansitesi - ortalama VKI VKI; Vücut Kitle İndeksi

Tümör çapı $2 \mathrm{~cm}$ ve daha küçük, 2-5 $\mathrm{cm}$ arasında ve $5 \mathrm{~cm}$ 'den büyük gruplara ayrıldığında dansite ile tümör çapı arasındaki dağııımının gruplar arasında istatistiksel olarak anlamlı olmadığı saptandı $(p=0,353)$ (Tablo 3 ).

Tümörler histolojik olarak alt gruplara ayrıldığında spesifik alt tip içermeyen duktal invaziv tümörlerin, lobüler, mix tip ve spesifik alt tip içeren gruplara göre her dansite grubunda daha sık görüldüğü saptandı $(\% 72,56)(p=0,030)$ (Tablo 3).
Östrojen reseptörü pozitif $(\% 79,64)$, Progesteron reseptörü pozitif $(\% 68,14)$, HER 2 negatif $(\% 69,91)$ tümörlerin toplamda daha sık görüldüğüancaköstrojen reseptörü, Progesteron reseptörü ve HER 2 pozitifliğinin meme dansite grupları ile ilişkisi değerlendirildiğinde, gruplar arasında istatistiksel olarak anlamlı fark olmadığı saptandı. Sırasıyla $(p=0,547)$, ( $p=0,120),(p=0,161)$ (Tablo 3$)$.

Immunohistokimyasal alt tiplendirme yapıldığında Luminal A, Luminal B, HER 
Tablo 3. Meme dansitelerine göre patolojik bulgular

\begin{tabular}{|c|c|c|c|c|c|c|c|c|c|}
\hline & \multicolumn{2}{|c|}{ Tip A } & \multicolumn{2}{|c|}{ Tip B } & \multicolumn{2}{|c|}{ Tip C } & \multicolumn{2}{|c|}{ Tip D } & \multirow[t]{2}{*}{$p$ değeri } \\
\hline & $\mathrm{n}$ & $\%$ & $\mathrm{n}$ & $\%$ & $\mathrm{n}$ & $\%$ & $\mathrm{n}$ & $\%$ & \\
\hline Hasta sayısı & 15 & 13,3 & 49 & 43,4 & 33 & 29,2 & 16 & 14,2 & \\
\hline \multicolumn{10}{|l|}{ Tümör boyutu } \\
\hline $\mathrm{T} 1 \leq 2 \mathrm{~cm}$ & 3 & 20,0 & 23 & 46,93 & 14 & 42,42 & 5 & 31,25 & 0,353 \\
\hline T2 $2-5 \mathrm{~cm}$ & 11 & 73,33 & 24 & 48,97 & 19 & 57,58 & 11 & 68,75 & \\
\hline $\mathrm{T} 3 \geq 5 \mathrm{~cm}$ & 1 & 6,66 & 2 & 4,0 & 0 & 0,0 & 0 & 0,0 & \\
\hline Tümör Çapı (mm) (ortalama $\pm S S)$ & \multicolumn{2}{|c|}{$30,73 \pm 14,30$} & \multicolumn{2}{|c|}{$23,00 \pm 10,67$} & \multicolumn{2}{|c|}{$23,61 \pm 10,97$} & \multicolumn{2}{|c|}{$24,69 \pm 8,001$} & 0,120 \\
\hline \multicolumn{10}{|l|}{ Tümör tipi } \\
\hline Duktal & 7 & 46,66 & 39 & 79,59 & 26 & 78,78 & 10 & 62,50 & 0,030 \\
\hline Lobuler & 4 & 26,66 & 2 & 4,08 & 2 & 6,06 & 1 & 6,25 & \\
\hline Mix & 0 & 0,0 & 2 & 4,08 & 1 & 3,03 & 3 & 18,75 & \\
\hline Özel tip & 4 & 26,66 & 6 & 12,24 & 4 & 12,12 & 2 & 12,50 & \\
\hline \multicolumn{10}{|l|}{ Reseptör } \\
\hline $\mathrm{ER}+$ & 13 & 86,66 & 41 & 83,67 & 24 & 72,72 & 12 & 75,0 & 0,547 \\
\hline ER - & 2 & 13,33 & 8 & 16,33 & 9 & 27,28 & 4 & 25,0 & \\
\hline $\mathrm{PR}+$ & 11 & 73,33 & 37 & 75,52 & 22 & 66,66 & 7 & 43,75 & 0,120 \\
\hline PR - & 4 & 26,66 & 12 & 24,48 & 11 & 33,33 & 9 & 56,25 & \\
\hline HER 2 + & 2 & 13,33 & 15 & 30,61 & 9 & 27,27 & 8 & 50,0 & 0,161 \\
\hline HER 2 - & 13 & 86,77 & 34 & 69,33 & 24 & 72,73 & 8 & 50,0 & \\
\hline \multicolumn{10}{|l|}{ Luminal tip } \\
\hline Luminal A & 5 & 31,25 & 10 & 20,40 & 6 & 18,18 & 0 & 0,0 & 0,179 \\
\hline Luminal B & 7 & 46,66 & 21 & 42,85 & 12 & 36,36 & 5 & 31,25 & \\
\hline HER 2 pozitif & 2 & 13,33 & 15 & 30,61 & 9 & 27,27 & 8 & 50,0 & \\
\hline Triple negatif & 1 & 6,66 & 3 & 6,12 & 6 & 18,18 & 3 & 18,75 & \\
\hline \multicolumn{10}{|l|}{ Ki 67} \\
\hline$<\% 25$ & 6 & 40,0 & 16 & 32,65 & 8 & 24,25 & 3 & 18,75 & 0,500 \\
\hline$>\% 25$ & 9 & 60,0 & 33 & 67,35 & 25 & 75,75 & 13 & 81,25 & \\
\hline \multicolumn{10}{|l|}{ Grade } \\
\hline I & 3 & 20,0 & 13 & 26,53 & 10 & 30,30 & 4 & 25,0 & 0,986 \\
\hline II & 8 & 53,33 & 24 & 48,97 & 17 & 51,51 & 8 & 75,0 & \\
\hline III & 4 & 26,67 & 12 & 24,59 & 6 & 18,19 & 4 & 25,0 & \\
\hline
\end{tabular}

SS; standart sapma, ER; Östrojen Reseptörü, PR; Progesteron Reseptörü

2 pozitif ve triple negatif tümörlerin meme dansitesine göre dağılımında istatistiksel olarak fark saptanmadı $(p=0,179)$ (Tablo 3 ).

Toplam hastaların \%70,8'inde Ki 67 değerinin $\% 25$ 'in üstünde olduğu saptandı. Meme dansite gruplarına göre Ki 67 değerinin \%25'in altında ve üstünde olduğu hastalar değerlendirildiğinde gruplar arasında istatistiksel açıdan fark olmadığı saptandı $(p=0,500)$ (Tablo 3$)$.

Tüm hastalar değerlendirildiğine en sık grade II tümörler $(\% 50,44)$ görülmekle beraber, meme dansite gruplarına göre tümör grade'leri değerlendirildiğinde, gruplar arasında istatistiksel açıdan fark saptanmadı $(p=0,986)$ (Tablo 3).

\section{Tartışma}

Meme dansitesinin yüksek olması günümüzde kabul gören meme kanseri risk faktörlerinden biri olarak değerlendirilmektedir $[7,13]$. Meme dansitesinin meme kanseri için yaştan ve diğer değişkenlerden bağımsız bir risk faktörü olduğunun gösterilmesi ile önemi artmıştır [7, 14, 15]. 
Memeyi oluşturan yapılardan stromal ve epiteliyal dokular yağ dokusundan daha fazla $X$ ışını tutar. Bunun sonucunda fibroglandüler dokular mamografik olarak beyaz renkli görünürken, yağ dokusu siyah görünür [16].

Meme dansitesini ölçmek için çeşitli yöntemler geliştirilmiştir. Meme dansitesinin ölçümü görsel değerlendirme ile ya da yarı otomatik ve tam otomatik dansite değerlendirme yazılımları ile yapılmaktadır [17].

Meme dansitesinin görsel değerlendirilmesi en sık American Collage of Radiology, Breast Imaging Reporting and Data System (BI-RADS) değerlendirme kriterlerine göre yapılmaktadır. Tablo 4'de BI-RADS kriterlerine göre meme dansite ölçümleri açıklanmıştır [18].

Tablo 4. BI-RADS kriterlerine göre meme dansitesinin değerlendirilmesi

\begin{tabular}{ll}
\hline Dansite değerlendirmesi & Meme dokusu özellikleri \\
\hline Tip A & Tama yakın yağ (glandüler yapı <\%25) \\
Tip B & Dağınık yoğunluklar (glandüler yapı \%25-50) \\
Tip C & Heterojen olarak yoğun (glandüler yapı \%50-75) \\
Tip D & Aşırı yoğun (glandüler yapı >\%75) \\
\hline
\end{tabular}

Diğer sık kullanılan iki görsel yöntem Wolfe ve Tabar Sınıflandırmalarıdır. Değerlendiren radyologun subjektif olarak değerlendirme riskini en aza indirebilmek üzere geliştirilmiş olan otomatik yazılımlardan en sık kullanılanlar Volpra ve Quantra'dır [19].

Meme dansitesi yaş, vücut kitle indeksi, bireyin östrojen maruziyeti, emzirme öyküsü, menopoz durumu gibi faktörlere bağlı olarak ömür boyunca aynı bireyde ve farklı bireyler arasında değişmektedir [20]. Bireylerin genetik yapısının dansite üzerinde etkili olduğu ikizler ve akrabalar üzerinde yapılan çalışmalar ile desteklenmiştir. Yapılan çalışmalar sonucu farklı etnik kökenleri olan bireylerde meme dansite oranlarının değişik olduğu gösterilmiş ve toplumlar arası farklılıkların bildirilmesi önerilmiştir [20, 21].

Tüm Dünya'da meme dansitesi, klinik ve patolojik değişkenlere göre değerlendirilmekte ve farklı genetik yapılara sahip toplumlar kendi verilerini sunmaktadır [20].

Çalışmamızda daha önce Batı ve Doğu ülkelerinde yapılan çalışmaların literatür verileri ile uyumlu olarak yaş ve meme dansitesinin negatif ilişkili olduğu, yaş arttıkça meme dansitesindeki düşüşün anlamlı olduğu gösterilmiştir.

İlerleyen yaş ile meme kanseri riski artmasına rağmen, meme dansite değerinin düşmesi paradoks oluşturmuştur. Bu durumu açıklamak için meme dansitesinin yüksek olduğu hastalarda görüntüleme yöntemlerinde ve fizik muayenede memedeki kitlenin tanınmasının zor olduğu ve interval meme kanseri oranlarının arttığını gösteren çalışmalar bulunmaktadır [22].

Yine Doğu ve Batı ülkelerinde yapılan çalışmalara benzer olarak hastaların menopoz durumu ile meme dansitesinin ilişkili olduğu, dansitesi yüksek olan hastaların daha çok premenopozal dönemde olduğu gösterilmiştir [7, 11, 23].

Meme dansitesi yüksek hastalar için radyolojik açıdan karşılaşılabilecek sıkıntılar göz önüne alındığında memenin değerlendirilmesi için gereklilik halinde meme ultrasonu, meme manyetik rezonans görüntülemesi ve meme tomosentezi gibi ileri tetkiklerin yapılması önerilmektedir [6, 24]. Ülkemizde premenopozal meme kanseri hastaları ve meme koruyucu cerrahi tedavi seçenekleri artmaktadır. Bu hastalar için görüntülemenin önemi tedavi ve takip aşamasında artmaktadır.

Hasta grubumuzda hastaların genel olarak aşırı kilolu ve obez grupta olduğu, kilo artışı ile beraber meme dansite oranlarında düşme olduğu saptanmıştır. Kilo artışı ve meme dansite düşüşü arasındaki negatif ilişki daha önce yapılan çalışmalarda meme dokusunda artan yağ oranı ile açıklanmıştır. Elde ettiğimiz veriler literatür verileri ile uyumlu olarak değerlendirilmiştir. Engmann ve ark.'nın [19] yaptığı çalışmada obezitenin arttığı durumlarda meme dansite yüksekliğinin kanser riskinde daha fazla artışa neden olduğu saptanmış, meme kanserinden korunma stratejileri arasında kilo kontrolünün önemi vurgulamıştır. 
Meme dansitesine göre meme kanserinin patolojik bulguları değerlendirildiğinde literatürde çok değişik veriler sunulmuştur [25].

Meme dansitesinin yüksek olduğu durumlarda meme kanserinin radyolojik olarak saptanmasının zor olduğu, bu nedenle daha büyük çapta tümörler ile karşılaşıldığı bildirilmiştir. Meme dansitesi yüksek hastaların daha sık takip edilmesi gerektiği, ek görüntüleme yöntemlerinden faydalanılması ve hastaların meme dansitesi yüksekliğinin bir risk faktörü olduğu hakkında bilgilendirilmesi önerilmiştir [24]. Buna karşın meme dansitesi ile tümör çapı arasında ilişki olmadığını bildiren yayınlar da mevcuttur. Çalışmamızda her bir dansite grubunda ortalama tümör boyutu $2 \mathrm{~cm}$ 'nin üzerinde bulunmuştur. Meme dansite gruplar arasında tümör boyutunun dağılımında ise anlamlı fark saptanmamıştır. Özmen ve ark. [3] tarafından 20.000 Türk meme kanseri hastaları üzerinde yapılan çalışmada ortalama tümör çapı $2,5 \pm 1,7 \mathrm{~cm}$ olarak bulunmuştur. Bu değer bizim çalışmamızda bulunan ortalama tümör çapı ile benzerlik göstermektedir.

Türkiye ve diğer ülkelerden yapılan çalışmaların literatür verileri ile uyumlu olarak tüm meme dansite grupları arasında tümör tipi olarak en sık invaziv duktal karsinom saptanmıştır.

Meme dansitesinin yüksekliği ile ER, PR pozitifliği arasında pozitif yönde bir etkileşim olacağı öne sürülmüş ancak Batı ülkelerinde yapılan çok merkezli, yüksek hasta sayılı çalışmalar sonucunda meme dansitesi ile ER, PR reseptör dağılımı arasında pozitif yönde bir ilişki bulunamamıştır [9, 25]. Bun karşın Kenya'da 123 hasta üzerinde yapılan bir çalışmada ER pozitif tümörlerin meme dansitesi yüksek olan grupta, triple negatif tümörlerin ise meme dansitesi düşük olan grupta daha sık görüldüğü bildirilmiştir. Benzer şekilde genel literatür verilerine göre meme dansitesi ile HER 2 pozitifliği arasında pozitif ya da negatif yönde bir ilişki bildirilmemiştir $[9,25]$. Türkiye verileri ile uyumlu olarak bizim hasta grubumuzda da $\mathrm{ER}+, \mathrm{PR}+$, HER 2- tümörler ile daha sık karşılaşılmıştır. Hasta grubumuzda meme dansitesine göre ER, PR, HER 2 pozitifliği açısından anlamlı bir değişiklik saptanmamıştır.

Tümörlerin immünohistokimyasal alt tipleri değerlendirildiğinde kendi hasta grubumuzda meme dansitesi ile arasında anlamlı bir fark saptanmamıştır. Bu konuda literatüdeki veriler de oldukça heterojendir. Arora ve ark. [25] ile Ma ve ark.'nın [22] yaptığı çalışmalarda meme dansitesi yüksek hastalarda Luminal Tip A tümörlerin daha sık saptandığı ancak triple negatif tümörler için farklılıklar olduğu bildirilmiştir.

Yapılan moleküler çalışmalarda meme dansitesinin yüksekliği ile Ki 67 seviyesinin artacağı ön görülmesine rağmen, klinik çalışmamızda Ki 67 indeksinin seviyesi ile meme dansitesi arasında anlamlı bir etkileşim olmadığı gösterilmiştir [9].

Hasta grubumuzda Türkiye verileri ile uyumlu olarak en sık grade 2 tümörler görülmüş, diğer patolojik değişkenlerde olduğu gibi meme dansitesi ve tümör grade'i arasında da anlamlı bir ilişki bulunamamıştır. Bu ilişkiye dair literatür verileri bizim bulgularımızla uyumlu olmakla beraber Duffy ve ark. [26] yaptığı çalışmada meme dansitesi yüksek olan grupta grade 3 tümörlerin daha sık görüldüğü bildirilmiştir.

Çalışmamızın kısıtlayıcı faktörleri arasına hasta sayımızın az olduğunu, meme dansitelerinin değerlendirilmesinde subjektif değerlendirme riski olan görsel BIRADS değerlendirme yöntemi kullanılmasını dahil edebiliriz. Bununla beraber hastaların boy, kilo ve menopoz durumu değerlendirilmesinde bazı hastaların verilerine dosya kayıtlarından ulaşamadık. Bu hastalarda telefon ile arayarak alınan bilgilerde hastaların o zamanki verilerini hatırlamalarında hatalar olabilmektedir. Meme kanseri risk faktörlerinden meme dansitesinin etkisini değerlendirmeye yönelik olarak, çok merkezli, radyolojik açıdan güçlendirilmiş, dosya verileri kayıt anında eksiksiz tutulmuş, meme dansitesi ve tümör biyolojisi ilişkisinin moleküler düzeyde de değerlendirileceği çalışmaların faydası olacağını düşünmekteyiz.

Sonuç olarak, meme dansitesi meme kanseri için modifiye edilebilen bir risk faktörüdür. Obezite durumu ve ortalama tümör boyutunun yüksek olması primer koruyucu önlemler üzerinde durmamız gerektiğini göstermektedir. Meme kanserine yönelik bilinçliliği artırmak ve kanserden koruyucu hayat tarzı değişikliklerine adapte olmak gerekmektedir. Meme dansitesi yüksek kişiler için daha sık aralıklarla ve ek görüntüleme yöntemleri ile rutin takiplerinin yapılması hayati önem arz eder.

Çıkar ilişkisi: Yazarlar çıkar ilişkisi olmadığını beyan eder. 


\section{Kaynaklar}

1. Torre LA, Bray F, Siegel RL, Ferlay J, Lortet Tieulent J, Jemal A. Global cancer statistics, 2012. CA Cancer J Clin 2015;65:87-108. https://doi.org/10.3322/ caac. 21262

2. Özmen V. Breast Cancer in Turkey: clinical and histopathological characteristics (Analysis of 13.240 Patients). J Breast Health 2014;10:98-105. https://doi. org/10.5152/tjbh.2014.1988

3. Özmen V, Özmen T, Doğru V. Breast cancer in Turkey; an analysis of 20.000 patients with breast cancer. Eur J Breast Health 2019;15:141-146. https://doi. org/10.5152/ejbh.2019.4890

4. Rojas K, Stuckey A. Breast cancer epidemiology and risk factors. Clin Obstet Gynecol 2016;59:651-672. https://doi.org/10.1097/GRF.0000000000000239

5. Fortner RT, Katzke V, Kühn T, Kaaks R. Obesity and breast cancer. Recent Results Cancer Res 2016;208:43-65. https://doi.org/10.1007/978-3-31942542-9_3

6. Huo CW, Chew GL, Britt KL, et al. Mammographic density-a review on the current understanding of its association with breast cancer. Breast Cancer Res Treat 2014;144:479-502. https://doi.org/10.1007/ s10549-014-2901-2

7. McCormack VA, dos Santos Silva I. Breast density and parenchymal patterns as markers of breast cancer risk: a meta-analysis. Cancer Epidemiol Biomarkers Prev 2006;15:1159-1169. https://doi.org/10.1158/10559965.EPI-06-0034

8. Sherratt MJ, McConnell JC, Streuli CH. Raised mammographic density: causative mechanisms and biological consequences. Breast Cancer Res 2016;18:45. https://doi.org/10.1186/s13058-016-07019

9. Huo CW, Chew G, Hill P, et al. High mammographic density is associated with an increase in stromal collagen and immune cells within the mammary epithelium. Breast Cancer Res 2015;17:79. https://doi. org/10.1186/s13058-015-0592-1

10. Shaikh AJ, Mullooly M, Sayed S, et al. Mammographic breast density and breast cancer molecular subtypes: the Kenyan-African aspect. Biomed Res Int 2018;2018:10. https://doi.org/10.1155/2018/6026315

11. Salem C,Atallah D, Safi J, etal. Breast density and breast cancer incidence in the Lebanese population: results from a retrospective multicenter study. Biomed Res Int 2017;2017:9. https://doi.org/10.1155/2017/7594953

12. Penault Llorca F, Radosevic Robin N. Ki67 assessment in breast cancer: an update. Pathology 2017;49:166171. https://doi.org/10.1016/j.pathol.2016.11.006

13. Boyd NF, Martin LJ, Yaffe MJ, Minkin S. Mammographic density: a hormonally responsive risk factor for breast cancer. Br Menopause Soc J 2006;12:186-193. https:// doi.org/10.1258/136218006779160436
14. Chiu SY, Duffy S, Yen AM, Tabár L, Smith RA, Chen $\mathrm{HH}$. Effect of baseline breast density on breast cancer incidence, stage, mortality, and screening parameters: 25-year follow-up of a Swedish mammographic screening. Cancer Epidemiol Biomarkers Prev 2010;19:1219-1228. https://doi.org/10.1158/10559965.EPI-09-1028

15. Pettersson A, Graff RE, Ursin G, et al. Mammographic density phenotypes and risk of breast cancer: a metaanalysis. J Natl Cancer Inst 2014;106:1-11. https://doi. org/10.1093/jnci/dju078

16. Johns PC, Yaffe MJ. X-ray characterisation of normal and neoplastic breast tissues. Phys Med Biol 1987;32:675-695. https://doi.org/10.1088/00319155/32/6/002

17. Oliver A, Tortajada M, Lladó X, et al. Breast density analysis using an automatic density segmentation algorithm. J Digit Imaging 2015;28:604-612. https://doi. org/10.1007/s10278-015-9777-5

18. Destounis SV, Santacroce A, Arieno A. Update on breast density, risk estimation, and supplemental screening. Am J Roentgenol 2020;214:296-305. https://doi.org/10.2214/AJR.19.21994

19. Engmann NJ, Scott CG, Jensen MR, et al. Combined effect of volumetric breast density and body mass index on breast cancer risk. Breast Cancer Res Treat 2019;177:165-173. https://doi.org/10.1007/s10549019-05283-z

20. Ursin G, Lillie EO, Lee E, et al. The relative importance of genetics and environment on mammographic density. Cancer Epidemiol Biomarkers Prev 2009;18:102-112. https://doi.org/10.1158/1055-9965.EPI-07-2857

21. Crest $A B$, Aiello EJ, Anderson ML, Buist DS. Varying levels of family history of breast cancer in relation to mammographic breast density (United States). Cancer Causes Control 2006;17:843-850. https://doi. org/10.1007/s10552-006-0026-6

22. Ma I, Dueck A, Gray R, et al. Clinical and self breast examination remain important in the era of modern screening. Ann Surg Oncol 2012;19:1484-1490. https:// doi.org/10.1245/s10434-011-2162-9

23. Bae JM, Kim EH. Breast density and risk of breast cancer in Asian women: a meta-analysis of observational studies. J Prev Med Public Health 2016;49:367-375. https://doi.org/10.3961/jpmph.16.054

24. Phi XA, Tagliafico A, Houssami N, Greuter MJW, de Bock GH. Digital breast tomosynthesis for breast cancer screening and diagnosis in women with dense breasts - a systematic review and meta-analysis. BMC Cancer 2018;18:380. https://doi.org/10.1186/s12885018-4263-3

25. Arora N, King TA, Jacks LM, et al. Impact of breast density on the presenting features of malignancy. Ann Surg Oncol 2010;17:211-218. https://doi.org/10.1245/ s10434-010-1237-3 
26. Duffy SW, Morrish OWE, Allgood PC, et al. Mammographic density and breast cancer risk in breast screening assessment cases and women with a family history of breast cancer. Eur J Cancer 2018;88:48-56. https://doi.org/10.1016/j.ejca.2017.10.022

Etik kurul onayı: Çalışma için, İstanbul Sancaktepe Şehit Prof. Dr. İlhan Varank Eğitim ve Araştırma Hastanesi, Girişimsel Olmayan Klinik Araştırmalar Etik Kurulu'nun 13 Ocak 2021 tarih ve 2021/71 karar numarası ile onay alındı.

\section{Yazarların makaleye olan katkıları}

N.T. çalışmanın ana fikrini kurgulamış, D.Y. verileri toplamıştır. L.Y. mamografi filmlerini, D.Y. patoloji verilerini analiz etmiştir. N.T. makalenin yazımında ana katkıyı sağlamıştır. Tüm yazarlar eleştirel geri bildirim sağlayarak ve araştırmanın, analizin ve makalenin şekillenmesine yardımcı oldular. 